\title{
Secondary new particle formation in Northern Finland Pallas site between the years 2000 and 2010
}

\author{
E. Asmi ${ }^{1}{ }^{*}$, N. Kivekäs ${ }^{1}$, V.-M. Kerminen ${ }^{1}$, M. Komppula ${ }^{1}$, A.-P. Hyvärinen ${ }^{1}$, J. Hatakka ${ }^{1}$, Y. Viisanen ${ }^{1}$, and \\ H. Lihavainen ${ }^{1}$ \\ ${ }^{1}$ Finnish Meteorological Institute, Erik Palménin aukio 1, 00560 Helsinki, Finland \\ * currently at: Laboratoire de Météorologie Physique, Université Blaise Pascal, Clermont-Ferrand, UMR6016, France \\ Received: 11 September 2011 - Published in Atmos. Chem. Phys. Discuss.: 15 September 2011 \\ Revised: 30 November 2011 - Accepted: 13 December 2011 - Published: 20 December 2011
}

\begin{abstract}
Secondary new particle formation affects atmospheric aerosol and cloud droplet numbers and thereby, the aerosol effects on climate. In this paper, the frequency of nucleation events and the associated particle formation and growth rates, along with their seasonal variation, was analysed based on over ten years of aerosol measurements conducted at the Pallas GAW station in northern Finland. The long-term measurements also allowed a detailed examination of factors possibly favouring or suppressing particle formation. Effects of meteorological parameters and air mass properties as well as vapour sources and sinks for particle formation frequency and event parameters were inspected. In addition, the potential of secondary particle formation to increase the concentration of cloud condensation nuclei $(\mathrm{CCN})$ sized particles was examined. Findings from these long-term measurements confirmed previous observations: event frequency peaked in spring and the highest growth rates were observed in summer, affiliated with increased biogenic activity. Events were almost exclusively observed in marine air masses on sunny cloud-free days. A low vapour sink by the background particle population as well as an elevated sulphuric acid concentration were found to favour particle formation. These were also conditions taking place most likely in marine air masses. Inter-annual trend showed a minimum in event frequency in 2003, when also the smallest annual median of growth rate was observed. This gives further evidence of the importance and sensitivity of particle formation for the condensing vapour concentrations at Pallas site. The particle formation was observed to increase $\mathrm{CCN}_{80}$ (>80 nm particle number) concentrations especially in summer and autumn seasons when the growth rates were
\end{abstract}

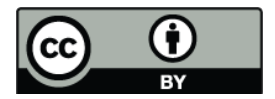

Correspondence to: E. Asmi (eija.asmi@fmi.fi) the highest. When the growing mode exceeded the selected $80 \mathrm{~nm}$ limit, on average in those cases, $211 \pm 114 \%$ increase of $\mathrm{CCN}_{80}$ concentrations was observed.

\section{Introduction}

Atmospheric new particle formation (NPF) has been observed to take place in a vast variety of environments, including clean and polluted continental boundary layers, coastal and some other marine areas, anthropogenic plumes, cloud outflows and free troposphere (Kulmala et al., 2004; Kulmala and Kerminen, 2008; O'Dowd et al., 2010). Field measurements show that newly-formed particles are often able to grow into cloud condensation nuclei (CCN) sizes (e.g., Lihavainen et al., 2003; Laaksonen et al., 2005; Wiedensohler et al., 2009), and to participate into cloud droplet activation (Kerminen et al., 2005). Almost all studies have found a close connection between NPF and gaseous sulphuric acid (Brus et al., 2011; Kuang et al., 2008; Kulmala et al., 2006; Paasonen et al., 2010; Riipinen et al., 2007; Sipilä et al., 2010; Weber et al., 1996). In most atmospheric environments, the rate of NPF appears to scale between the first and second power of the gaseous sulphuric acid concentration, being indicative of either activation (Kulmala et al., 2006) or kinetic-type (McMurry and Friedlander, 1979) formation process. Besides sulphuric acid, NPF may be affected by ammonia or amines (Benson et al., 2011; Berndt et al., 2010; Kurtén et al., 2008; Smith et al., 2010), low-volatile organic vapors (Metzger et al., 2010; Paasonen et al., 2010), or iodine compounds (O'Dowd et al., 2002; Vuollekoski et al., 2009). The role of ions in atmospheric NPF has remained the subject of large debate (Gagné et al., 2010; Hirsikko et al., 2011; Kazil et al., 2008; Yu, 2010a).

Published by Copernicus Publications on behalf of the European Geosciences Union. 
Uncertainties in particle formation processes are translated into uncertainties in aerosol-cloud interactions and indirect climate forcing by aerosols (e.g., Kazil et al., 2010; Makkonen et al., 2009; Pierce and Adams, 2009; Wang and Penner, 2009). While the exact mechanisms and compounds participating in atmospheric NPF have remained poorly understood (Kerminen et al., 2010), semi-empirical and other nucleation schemes have been used in global models to estimate the contribution of NPF to aerosol burden and climate forcing. These investigations have shown that atmospheric NPF is very likely to be the dominant source of the aerosol number concentration in the global troposphere (Kazil et al., 2010; Spracklen et al., 2006, 2010; Yu et al., 2010b), and to increase $\mathrm{CCN}$ and cloud droplet number concentrations by up to several tens of percents in the lower atmosphere (Merikanto et al., 2009, 2010; Pierce and Adams, 2009).

Field studies made in Northern Europe have revealed that NPF events usually take place on $20-60 \%$ of all days (Dal Maso et al., 2005; Dal Maso et al., 2007; Kristensson et al., 2008; Vehkamäki et al., 2004). Similar NPF frequencies have been observed in most other European sites (Manninen et al., 2010), as well as in Australian eucalyptus forest (Suni et al., 2008) and in Indian Himalayas (Neitola et al., 2011). The factors controlling NPF and its seasonal occurrence seem to vary largely between different locations. In Northern Europe, NPF is associated with clean Arctic or Atlantic air masses and is most common during the spring months (Dal Maso et al., 2007; Komppula et al., 2003). This is contrary to India where high concentrations of condensable vapors from polluted regions seem to be required for NPF to occur (Neitola et al., 2011). An exceptional seasonal pattern of NPF with a winter maximum has been reported in Hohenpeissenberg, Germany (Birmili et al., 2003). Most NPF events occur during daytime, probably as a result of active photochemistry and enhanced vertical mixing (e.g., Kulmala and Kerminen, 2008). NPF has been found to be suppressed by the presence of clouds or rain, high relative humidity, and low amount of solar radiation (Hamed et al., 2011; Sogacheva et al., 2008). In continental European boundary layers, NPF is likely to be dominated by neutral formation pathways, the contribution of ions being most important in the cleanest environments (Manninen et al., 2010).

In order to get better understanding on atmospheric NPF and to further improve its representation in global modeling frameworks, more information on new-particle formation and growth rates, on their association with trace gases and meteorological conditions, as well as on general conditions favoring or hindering NPF are required from different types of environments. Of particular importance in this regard are consistent long-term observations. In the current paper, we will investigate NPF in a remote sub-Arctic site based on more than 10 years of continuous aerosol, trace gas and meteorological measurements. The Arctic location of the measurement site highlights the strong seasonal meteorological variability and aerosol natural influences far from anthropogenic sources. In addition to investigating newparticle formation and growth rates and their connections with other measured quantities, we will estimate the contribution of NPF to atmospheric CCN production. Our overall goal is to find out the atmospheric conditions necessary for NPF over the examined region and to further inspect the data for the long-term trends and changes.

\section{Methods}

The measurements were conducted in years 2000-2010 in Northern Finland at a sub-Arctic Global Atmospheric Watch (GAW) station Pallas $\left(67^{\circ} 58^{\prime} \mathrm{N}, 24^{\circ} 07^{\prime} \mathrm{E}, 560 \mathrm{~m}\right.$ a.s.1.). The station is located on a hill top at the edge of the boreal forest zone about $200 \mathrm{~km}$ from the Arctic Ocean. Detailed description of the measurement site can be found in Aalto et al. (2002); Komppula et al. (2003).

\subsection{Measurements and instrumentation}

Particle number size distributions were measured using Differential Mobility Particle Sizer (DMPS). The size range of the instrument extends from 7 to $500 \mathrm{~nm}$ in diameter. Particle sizes are selected using a Hauke type differential mobility analyser which is followed by a TSI model 3010 condensation particle counter. The inlet has an upper size-cut of approximately $2 \mu \mathrm{m}$, after which the aerosol is dried with permapure nafion dryer and neutralised with a bipolar diffusion charger $(85-\mathrm{Kr})$ before entering the inlet of DMPS. Details of the instrumentation and setup are described by Komppula et al. (2003). The measurements started in April 2000 and the analysed period extends from the beginning until the end of December 2010 with a data coverage presented in Fig. 1.

Auxiliary $\mathrm{SO}_{2}$ concentration data was measured with Thermo Electron 43S analyser which uses fluorescence detection method. Meteorological parameters including wind speed and direction, temperature, relative humidity and solar radiation were measured with a Vaisala automatic weather station. Visibility, precipitation intensity and type were measured with Vaisala FD12P present weather sensor.

\subsection{Analysis}

The days within the measurement period were first classified into new particle formation (NPF) event days, no-NPF days and undefined days, following the method presented by Dal Maso et al. (2005). NPF events were further divided into class I and class II, with the principal difference that class I events showed continuous, well-defined growth of the particles starting at the smallest measurable size of $7 \mathrm{~nm}$. In contrast, class II events showed more concentration fluctuations and thereby, the particle growth rates were defined with lesser accuracy. Days with missing or bad data were defined as unclassified. 
To calculate the particle formation and growth rates, we assumed the new particle formation occurred simultaneously and equally in a wide area of the air mass. For class I events, showing well-defined continuous particle growth, this assumption is well justified. Particle growth rates $\left(\mathrm{nm} \mathrm{h}^{-1}\right)$ were calculated as in Hamed et al. (2007); Neitola et al. (2011) and Kulmala et al. (2001) following the growing mode peak diameter. To retain the consistency with earlier NPF studies in Pallas, the particle formation rates at $7 \mathrm{~nm}$ (available only for class I events) were calculated similarly as in Komppula et al. (2003) and Mäkelä et al. (2000). This method follows the increase of nucleation mode number concentration with time with a user input of mode maximum diameter. In addition to previous studies, extra-modal coagulation losses were considered in the analysis, for which the particle atmospheric "wet diameters" were calculated using hygroscopicity parameterisation for boreal forest conditions as presented by Laakso et al. (2004). The same parameterisation was used to calculate the wet diameters for vapour condensational sink (CS) which was determined from measured size distributions as suggested by Kulmala et al. (2001).

Air mass backward trajectories for the arrival pressure level of $925 \mathrm{hPa}$ were calculated with the FLEXTRA kinematic trajectory model (Stohl et al., 1995; Stohl and Seibert, 1998) using meteorological model data from ECMWF (European Centre for Medium Range Weather Forecasts). Trajectories were calculated every three hours starting at 02:00 local winter time (UTC+2) following the air mass $120 \mathrm{~h}$ backwards in one-hour time steps. For dividing the air masses into characteristic types, distance weighted fractions were used. It has been shown that NPF observed in northern Finland typically occurs in the proximity of the station (Hussein et al., 2009), and thus it is justified to give more weight to the nearest trajectory points. Here the weigh was set to be a linear function of time such that the weight decreased from 1 to $0.0769(10 / 130)$ during the $120 \mathrm{~h}$. This way, the sum of the weights given for the trajectory points at nearest $24 \mathrm{~h}$ is $34 \%$, while the weights for the points at four following days are $27,20,13$, and $6 \%$. Therefore, even if the trajectory path is over the ocean during the first three days (hours 48-120 backwards), the air mass can be classified as $61 \%$ continental based on the most recent trajectory path. The division to characteristic types (marine, continental and mixed) is explained in detail in following section "air mass properties".

\section{Results}

\subsection{Seasonal cycle and characteristics of new particle formation}

Consistent with earlier studies at Pallas (e.g., Komppula et al., 2003), a pronounced seasonal cycle in NPF frequency with winter minimum and spring maximum was

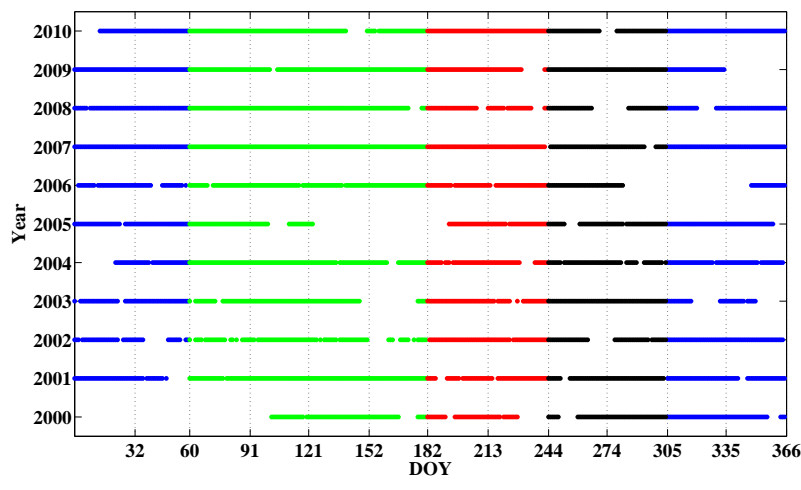

Fig. 1. Data coverage for different years (y-axis) as a function of day-of-year (DOY). Seasons are separated with colours, blue being indicative for winter, green for spring, red for summer and black for autumn, as they are refered in the text.

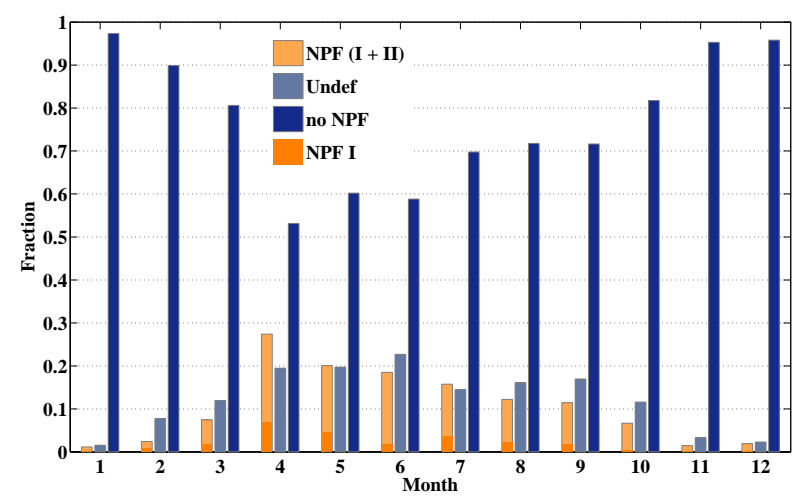

Fig. 2. Fraction of NPF event (classes I and II separately), undefined and non-event days in each month.

found (Fig. 2). The highest fraction of NPF days, around 0.27 , was observed in April. The NPF fraction decreased gradually towards the autumn months being only 0.06 in September. However, compared to the spring season a relatively higher fraction of undefined days was detected in late summer and autumn. In winter the NPF days were truly sporadic. The fraction of no-NPF days was the highest in winter $(0.8-1.0)$ and the lowest in spring and early summer $(0.5-$ 0.6 ), thus opposite to the seasonal cycle of NPF and undefined days.

The observed seasonal NPF pattern with a spring maximum and winter minimum is typical for all Nordic stations (Dal Maso et al., 2007; Kristensson et al., 2008; Vehkamäki et al., 2004). However, in southern Nordic stations (Hyytiälä in Finland, Aspvreten and Vavihill in Sweden) an additional summer minimum around July is observed, and can be at least partly explained by the increasing fraction of undefined 


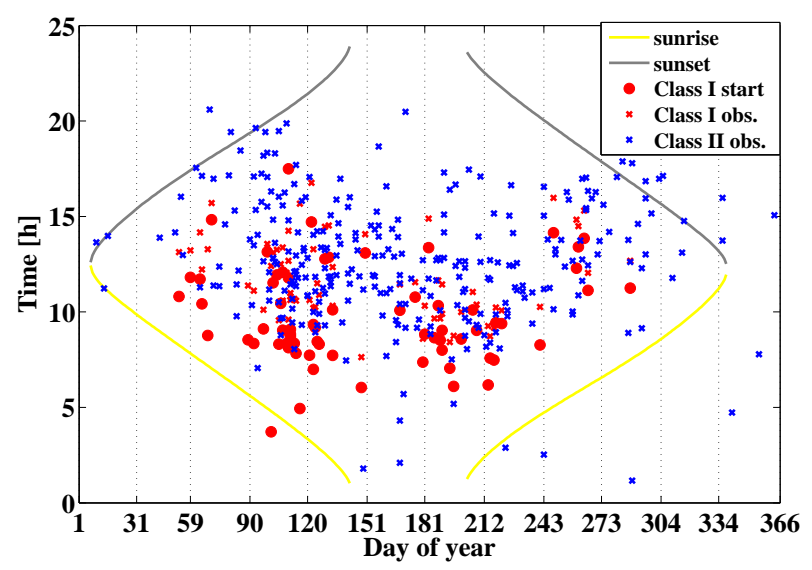

Fig. 3. Starting time of the NPF events, extrapolated backwards to $2 \mathrm{~nm}$ for class I events (red circles), and observations times both for class I and class II events (red and blue crosses).

days in summer (Buenrostro Mazon et al., 2009). In contrast, in Pallas, the fraction of undefined days did not show a peak in summer but remained relatively constant during April-September months. By further comparing the southern and northern Nordic stations, it can also be seen that events are much more frequent in southern stations.

Altogether $68 \mathrm{NPF}$ class I events were detected for which the particle growth rates (GR) and the $7 \mathrm{~nm}$ particle formation rates $\left(\mathrm{FR}_{7}\right)$ could be well determined. Their monthly statistics are presented in Table 1. The value of $\mathrm{FR}_{7}$ appears affected little by the seasonal variation, although the highest values $\left(>0.5 \mathrm{~cm}^{-3} \mathrm{~s}^{-1}\right)$ were observed in March and April. The monthly average value of $\mathrm{FR}_{7}$ varied between 0.1 and $0.2 \mathrm{~cm}^{-3} \mathrm{~s}^{-1}$. The missing seasonal variability in particle formation rates is in line with previous studies from Northern Finland (Komppula et al., 2006; Vehkamäki et al., 2004), allthough a partial explanation could also be related to the relatively large lower detection limit of the particle diameter. While the growth time of 1-2 nm particles up to the detection diameter of $7 \mathrm{~nm}$ can be on the order of several hours, the observed formation rates reflect the initial nucleation rates insufficiently, as is also pointed out by Komppula et al. (2006). In particle growth rates a seasonal pattern was more evident, with a summer maximum between June and August, possibly affiliated with particle precursors from increased biogenic activity. The values of GR showed a large variability between 0.4 and $12.4 \mathrm{~nm} \mathrm{~h}^{-1}$ whereas monthly-average GR ranged from around $2 \mathrm{~nm} \mathrm{~h}^{-1}$ in February-March to over $4 \mathrm{~nm} \mathrm{~h}^{-1}$ in June-July.

A vast majority of global atmospheric new particle formation events are detected during daytime (Kulmala and Kerminen, 2008). We estimated the starting times of each class I event by assuming that nucleation had produced $2-\mathrm{nm}$ particles which then grew to measurable sizes (above $7 \mathrm{~nm}$ ) at
Table 1. Monthly mean (std) values and ranges for $7 \mathrm{~nm}$ particle formation rates $\left(\mathrm{FR}_{7}\right)\left[\mathrm{cm}^{-3} \mathrm{~s}^{-1}\right]$ and for particle growth rates (GR) $\left[\mathrm{nm} \mathrm{h}^{-1}\right]$. The last column shows the total number (n) of class I NPF events used in $\mathrm{FR}_{7}$ and GR calculations.

\begin{tabular}{lrrl}
\hline Month & $\mathrm{FR}_{7}$ mean \pm std (range) & GR mean \pm std (range) & $n$ \\
\hline 1 & - & - & 0 \\
2 & $0.11 \pm 0.06(0.07-0.15)$ & $2.0 \pm 0.1(2.0-2.1)$ & 2 \\
3 & $0.21 \pm 0.24(0.06-0.64)$ & $1.9 \pm 1.0(1.0-3.5)$ & 5 \\
4 & $0.19 \pm 0.14(0.07-0.58)$ & $2.4 \pm 2.5(0.4-12.4)$ & 21 \\
5 & $0.13 \pm 0.05(0.06-0.21)$ & $2.2 \pm 0.9(1.1-4.1)$ & 13 \\
6 & $0.14 \pm 0.08(0.06-0.25)$ & $4.6 \pm 1.0(3.7-6.0)$ & 4 \\
7 & $0.18 \pm 0.10(0.07-0.44)$ & $4.0 \pm 1.2(1.6-6.2)$ & 11 \\
8 & $0.13 \pm 0.09(0.04-0.30)$ & $3.8 \pm 2.5(1.2-7.7)$ & 6 \\
9 & $0.20 \pm 0.10(0.09-0.30)$ & $2.9 \pm 1.3(2.1-5.2)$ & 5 \\
10 & $0.13 \pm 0.00(0.13)$ & $3.3 \pm 0.0(3.3)$ & 1 \\
11 & - & - & 0 \\
12 & - & - & 0 \\
\hline
\end{tabular}

the same GR as determined for the NPF event. The starting times of class II events, for which the GR could not be well determined, were replaced with the times at which the events were first observed. The assumption of constant GR with size can be justified by the analysis of Manninen et al. (2010), where it was shown that GR at Pallas site does not have a strong size dependency. The results of calculated class I NPF event starting times, along with those of class II events, are presented as a function of the day of year in Fig. 3. The coupling of the start of the event with the time of day is evident, while the appearance of NPF is concentrated around the daytime hours. Most of the class I event nucleation times appear between 07:00 and noon. A minor shift towards the morning hours in summer can be connected with the earlier sunrise. This effect is, however, weak compared to the large seasonal variation of daytime length. The class II event starting times varied more broadly, which could for a major part be explained by the variation of particle growth rates prior to the observations. In late autumn, few class II events were also detected during late polar night. These events suggest that NPF can, in rare cases, occur also in the absence of solar radiation.

\subsection{Factors connected with NPF}

\subsubsection{Air mass properties}

Previous studies have found a strong positive correlation between north-western air masses and probability of NPF at the Nordic stations (Dal Maso et al., 2007). In order to examine whether the same holds for the long time series of NPF events observed in Pallas, we divided the air mass source regions into five categories, namely Arctic, Eastern, Southern, Western and Local (Fig. 4). Based on the weighted fractions of air masses over these source regions, for each trajectory the region of the highest weight was considered to represent 
Table 2. Seasonal airmass frequencies in percents on all days, and at the beginning of the observation of NPF class I (CLI) and NPF class II (CLII) events. The numbers in parentheses give the number of cases. Airmass types are divided as presented in Fig. 1. Additionally, airmasses were divided into marine ( $>70 \%$ over sections I and II), continental (Cont., $>70 \%$ over sections III, IV and V) and mixed groups.

\begin{tabular}{lccc|ccc|ccc|cc|c}
\hline & \multicolumn{3}{c}{ Winter (Nov-Feb) } & \multicolumn{3}{c|}{ Spring (Mar-Jun) } & \multicolumn{3}{c}{ Summer (Jul-Aug) } & \multicolumn{2}{c}{ Autumn (Sep-Oct) } \\
\cline { 2 - 12 } & All & CLI (2) & CLII (16) & All & CLI (43) & CLII (165) & All & CLI (17) & CLII (67) & All & CLI (6) & CLII (46) \\
\hline Arctic & 31 & 50 & 13 & 39 & 63 & 58 & 29 & 71 & 52 & 36 & 83 & 50 \\
East & 18 & 50 & 13 & 14 & 7 & 4 & 14 & 0 & 6 & 10 & 0 & 7 \\
South & 28 & 0 & 19 & 20 & 0 & 9 & 25 & 0 & 4 & 26 & 17 & 11 \\
West & 15 & 0 & 50 & 14 & 28 & 22 & 14 & 24 & 24 & 19 & 0 & 24 \\
Local & 9 & 0 & 6 & 12 & 2 & 7 & 18 & 6 & 13 & 10 & 0 & 9 \\
\hline Mixed & 24 & 50 & 25 & 30 & 28 & 32 & 29 & 12 & 34 & 27 & 17 & 20 \\
Marine & 31 & 0 & 38 & 34 & 65 & 58 & 25 & 82 & 54 & 37 & 83 \\
Cont. & 45 & 50 & 38 & 36 & 7 & 10 & 46 & 6 & 12 & 36 & 0 \\
\hline
\end{tabular}

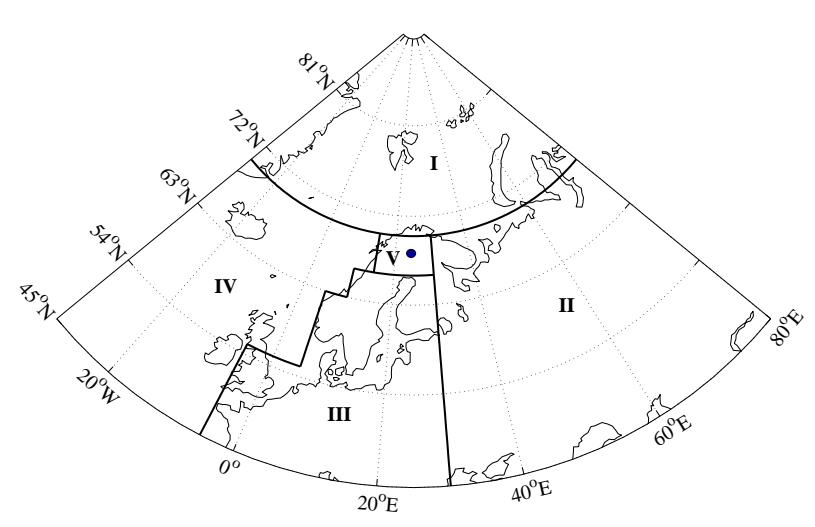

Fig. 4. Map of airmass sectors: I (Arctic), II (East), III (South), IV (West) and V (Local).

this air mass type. Table 2 presents the seasonal frequencies of air mass types along with the corresponding values during NPF. The seasonal division differs from the conventional classification, emphasising the long and dark Northern winter (November-February) and the late and short summer (July-August). Additionally, the air masses were divided between marine, mixed and continental types. Marine air masses represented the cases where $>70 \%$ of the trajectory weight was over Arctic and western regions (I and IV, see map in Fig. 4), continental those where $>70 \%$ of the trajectory weight was over eastern, southern and local regions (II, III, V) and mixed air masses represented the remaining cases in between.

During all seasons, NPF was commonly detected in Arctic and western (i.e. marine) air masses (Table 2). Arctic air mass was also the predominant type during all seasons, though being closely followed by the occurrence of southern air mass type. The fraction of Arctic air masses decreased in summer, which in part might explain the observed lower NPF frequency as compared to spring. A comparison between marine and continental cases confirms that NPF is rarely observed in continental air masses, despite the dominance of this air mass type over the marine type throughout the seasons. To resolve the principal differences between marine and continental air masses and the factors presumably affecting the NPF within these, the following analysis will be done separately for each of the air mass types.

\subsubsection{Meteorological variables}

The measured meteorological variables (temperature, relative humidity, wind speed, global solar radiation, visibility, rain occurrence) varied with both season and air mass type (Table 3). The marine air masses, in general, were dryer (both rain occurence and relative humidity $(\mathrm{RH})$ were lower) and brighter (solar radiation and visibility were higher). These features seemed to favour particle formation: both RH and raininess in NPF days were lower than their seasonal medians for any of the air mass types and similarly, both solar radiation and visibility in NPF days were typically higher. An exception was the winter season, when high values of $\mathrm{RH}$ and low values of solar radiation were seen in all the air mass types, manifesting the cold and dark Arctic winters. Low temperatures in winter can further suppress the biogenic activity combined with low radiation inhibiting the oxidation of secondary vapours. Thereby, these winter meteorological features are suspectedly behind the observed low NPF frequency in winter, as has also been suggested in a number of previous studies (e.g., Dal Maso et al., 2005; Komppula et al., 2003, 2005).

The strong coupling between air mass types and meteorological features complicates the separation between individual factor effects on NPF. While the marine air masses seemed to hold many of the meteorological features favoring the NPF, the role of additional factors connected with the air masses could not be excluded. Therefore, we examined the predictability of NPF occurrence of a proxy solely based on 
Table 3. Median daytime (hours 11:00-13:00 LWT) meteorological parameters at different seasons separately for different air mass types. In addition, seasonal medians for NPF start times are presented.

\begin{tabular}{|c|c|c|c|c|c|c|c|}
\hline & & $T\left[{ }^{\circ} \mathrm{C}\right]$ & $\mathrm{RH}[\%]$ & $\mathrm{Ws}\left[\mathrm{ms}^{-1}\right]$ & $\operatorname{Rad}\left[\mathrm{W} \mathrm{m}^{-2}\right]$ & Vis $[\mathrm{km}]$ & Rain [\%] \\
\hline \multirow{4}{*}{ Winter } & Marine & -7.6 & 93 & 7.5 & 12 & 45.7 & 3.2 \\
\hline & Mixed & -8.3 & 93 & 7.0 & 8 & 17.1 & 15.3 \\
\hline & Cont. & -9.3 & 93 & 7.3 & 5 & 1.9 & 26.6 \\
\hline & NPF & -3.3 & 95 & 7.5 & 1 & 49.9 & 0.0 \\
\hline \multirow{4}{*}{ Spring } & Marine & 0.1 & 66 & 6.7 & 399 & 43.8 & 6.5 \\
\hline & Mixed & 1.6 & 70 & 5.5 & 411 & 41.8 & 12.3 \\
\hline & Cont. & 1.6 & 88 & 5.9 & 279 & 33.0 & 18.1 \\
\hline & NPF & 0.7 & 60 & 6.2 & 422 & 46.7 & 3.0 \\
\hline \multirow{4}{*}{ Summer } & Marine & 9.7 & 68 & 5.8 & 408 & 47.2 & 6.7 \\
\hline & Mixed & 11.5 & 71 & 4.4 & 386 & 46.4 & 12.3 \\
\hline & Cont. & 14.4 & 78 & 4.9 & 349 & 41.8 & 19.2 \\
\hline & NPF & 10.4 & 64 & 5.3 & 445 & 48.1 & 6.2 \\
\hline \multirow{4}{*}{ Autumn } & Marine & 1.4 & 86 & 6.4 & 201 & 47.5 & 3.3 \\
\hline & Mixed & 2.2 & 94 & 5.4 & 124 & 43.4 & 12.3 \\
\hline & Cont. & 4.5 & 98 & 6.2 & 71 & 0.4 & 34.4 \\
\hline & NPF & 3.2 & 80 & 5.4 & 107 & 49.9 & 2.0 \\
\hline
\end{tabular}

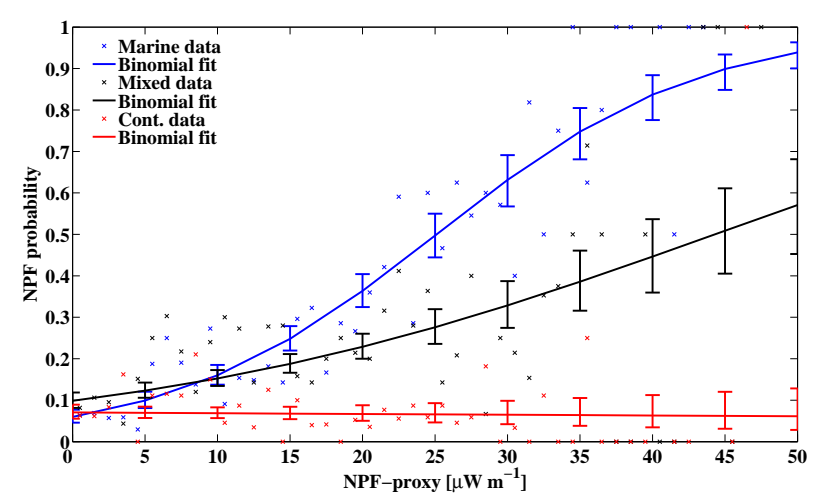

Fig. 5. Probability of a NPF event at different air masses using a NPF-proxy (visibility $\times$ global radiation). Different colours are used to mark the air mass types.

global solar radiation and visibility but separated between the air mass types. Solar radiation and visibility were chosen as meteorological proxy variables because they are also linked with cloudiness and condensation sink, which are generally connected to NPF. In marine air masses this NPF-proxy (solar radiation $\times$ visibility) seemed as a good predictor; NPF probability increased with increasing proxy (Fig. 5). In contrast, in continental air masses the NPF probability remained low at all proxy values, thereby indicating that these meteorological conditions were irrelevant for continental NPF in Pallas.

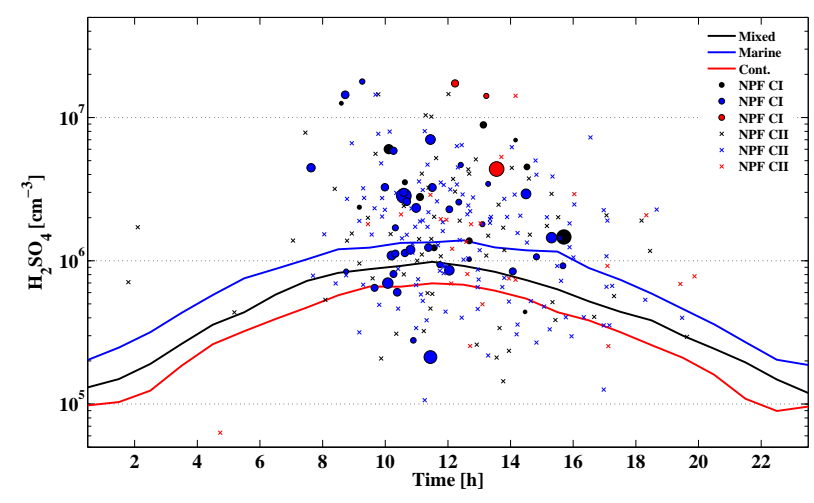

Fig. 6. Median sulphuric acid concentration as a function of timeof-day (lines) and separately, for NPF event start times at $7 \mathrm{~nm}$ (dots and crosses). Different colours are used to mark the air mass types and for class I (CI) events, the symbol size shows the particle formation rate.

\subsubsection{Sulphuric acid and CS}

Sulphuric acid has been suggested as a key species for NPF (e.g., Brus et al., 2011; Kulmala et al., 2006; Sipilä et al., 2010). The sulphuric acid was not directly measured at Pallas site but calculated here using a proxy

$\mathrm{H}_{2} \mathrm{SO}_{4}=k \times \frac{\mathrm{SO}_{2} \times \mathrm{Glob}}{\mathrm{CS}}$

based on global solar radiation (Glob), sulphur dioxide concentration $\left(\mathrm{SO}_{2}\right)$ and condensation sink (CS) as suggested by 
Petäjä et al. (2009) in boreal forest conditions. The pre-factor $k$ also depends on the global solar radiation as presented in Petäjä et al. (2009, in Fig. 2).

The sulphuric acid proxy did not show a clear seasonal pattern, but it had a strong diurnal cycle and was dependent on the air mass type (Fig. 6). The median proxy concentration was the highest in marine and the lowest in continental air masses throughout the day, with maxima between 0.7 and $1.4 \mathrm{e}^{6} \mathrm{~cm}^{-3}$ observed around midday. In general, the sulphuric acid concentration was also higher at the NPF observation times when compared to the concentration median, although the deviation in calculated $\mathrm{H}_{2} \mathrm{SO}_{4}$ proxy values was large. This suggests that sulphuric acid is important for NPF and again, marine air masses seem to favour particle formation in this respect. Also plotted is the $7 \mathrm{~nm}$ particle formation rate which, contradictory to pre-expectations (e.g., Sipilä et al., 2010), did not show a clear dependency on the sulphuric acid concentration. A reason for this could be the uncertainties arising from the time delay between the actual nucleation process and the observed particle formation, as well as the determination of sulphuric acid concentrations using a proxy instead of direct measurements. Another explanation could be additional vapours contributing to particle formation, as has been suggested in a some studies (Metzger et al., 2010; Paasonen et al., 2010).

The fraction of particle growth explained by sulphuric acid condensation was estimated based on Kulmala et al. (1998) as

$\mathrm{GR}=\frac{m_{v} \beta_{m} D C}{r \rho}$,

where $m_{v}$ is the sulphuric acid molecular mass of $98 \mathrm{amu}$, $\beta_{m}$ is the transitional correction factor, $D$ is the diffusion coefficient $\left(0.1 \mathrm{~cm}^{2} \mathrm{~s}^{-1}\right.$ used $), r$ is the particle radius, $\rho$ is the particle density $\left(1.0 \mathrm{~g} \mathrm{~cm}^{-3}\right)$ and $C$ the calculated sulphuric acid concentration. Excluding the winter time, the majority of the nuclei growth (60-95\%) was found to be explained by something else than sulphuric acid condensation (Fig. 7). The main candidates in this respect are low-volatile organic vapours originating from regional biogenic emissions.

Condensation sink (CS), derived from the pre-existing particle number size distribution (Kulmala et al., 2001), describes the loss rate of condensable vapour molecules, which links it to the nucleating and condensating vapour concentrations. Additionally the CS connects with the loss rate of newly formed small clusters due to its relation with coagulation sink. Therefore, high values of CS can suppress NPF even at sufficiently high nucleating vapour concentrations.

Condensation sink had a clear seasonal variation, but its values were also significantly different between the air mass types (Fig. 8): the sink was the highest in continental air masses and the lowest in marine ones. At times of the NPF observations, the condensation sink values were generally below the corresponding air mass medians and NPF was rarely seen at typical continental CS values (Fig. 8). This

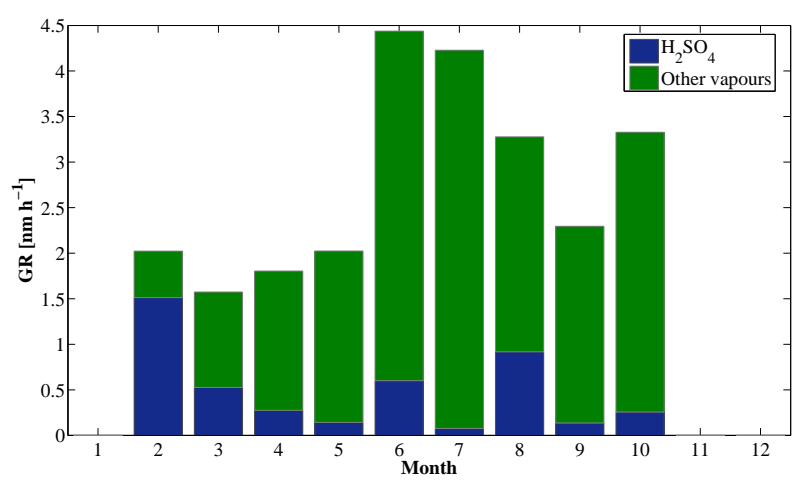

Fig. 7. The growth rate (GR) explained by the sulphuric acid and other vapours (median values for each month).

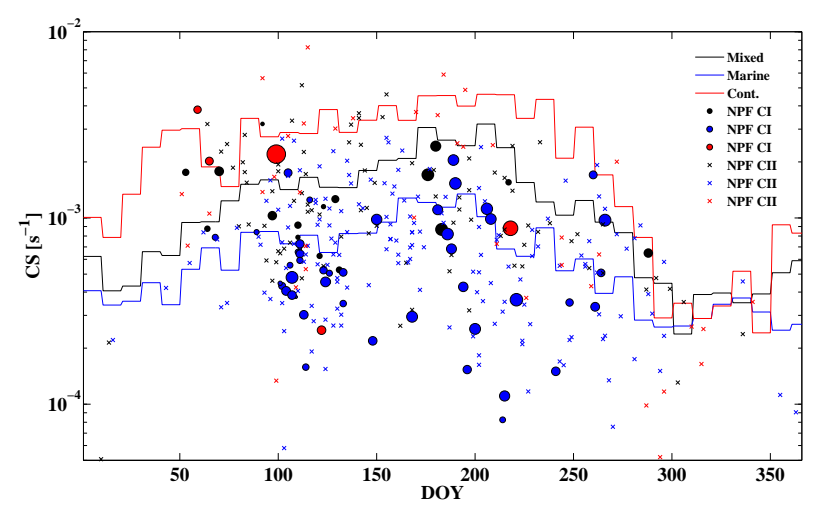

Fig. 8. 10-day median condensation sink (CS) as a function of day of year (DOY) (lines) for all days, including event, undefined and no-event days. Condensation sink for NPF class I and class II event start times at $7 \mathrm{~nm}$ is presented with dots and crosses. Different colours are used to mark the airmass types and for class I (CI) events, the symbol size shows the particle growth rate.

suggests that a high condensation sink is one of the factors inhibiting new particle formation in continental air masses. Reasons for the NPF dependency on CS can be that (i) at low values of CS nucleating and condensing vapours are more adundant, but also that (ii) the initially formed clusters become not too quickly scavenged by the pre-existing particles.

\subsubsection{Biogenic emissions}

Following the procedure presented by Tunved et al. (2006), we calculated the approximative latitude and temperature dependent emissions of biogenic monoterpenes in marine and mixed air masses. Indeed, the particle growth rate seemed to increase with increasing monoterpene emissions in the air mass (Fig. 9). In the cumulative emission range from 750 to $4250 \mu \mathrm{g} \mathrm{m}^{-2}$, the median GR increased from $1 \mathrm{~nm} \mathrm{~h}^{-1}$ to 


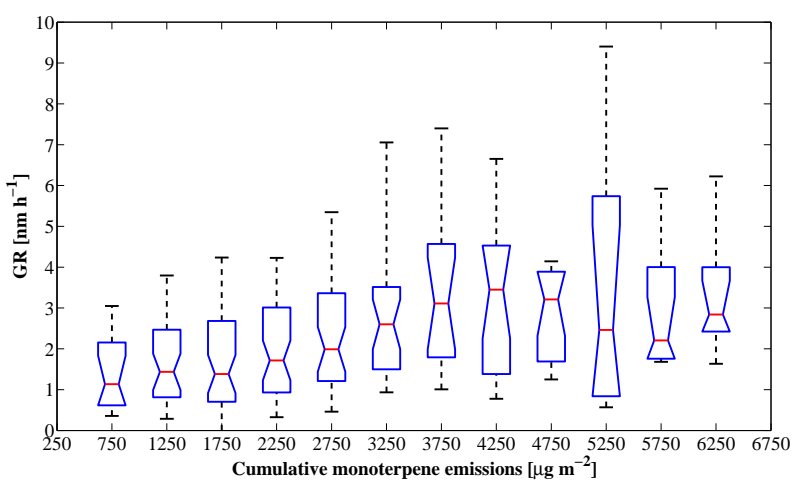

Fig. 9. Growth rate as a function of calculated cumulative monoterpene emissions (note, continental air masses are not included). The boxes show upper and lower quartiles, and median with red line. The whiskers extend from minimum to maximum GR value. For each box, a minimum of ten events were required and both class I and II events were included for statistical reasoning.

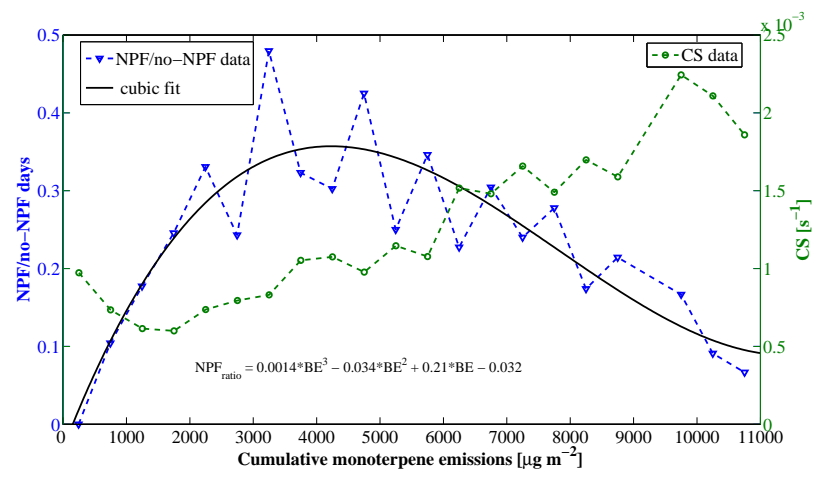

Fig. 10. New particle formation days (NPF) versus non-event days (no-NPF) as a function of daily median calculated cumulative monoterpene emissions calculated for air masses with over $50 \%$ of marine origin. Minimum of ten classified (marine influental) days were required for each data point. The cubic fit presents the $\mathrm{NPF}_{\text {ratio }}$ as a function of Biogenic monoterpene Emissions (BE). On a second y-axis the condensation sink (CS) as a function of monoterpene emissions in marine (over $50 \%$ ) air masses is shown.

about $3.5 \mathrm{~nm} \mathrm{~h}^{-1}$. However, after this limit, further increase in biogenic emissions was not followed by a linear increase of GR.

Similarly, an increase of NPF probability up to cumulative monoterpene emissions of around $4000 \mu \mathrm{g} \mathrm{m}^{-2}$ was detected, whereafter the probability decreased (Fig. 10). This can be partly explained by the increasing condensation sink with increasing time over land, which would thereby decrease the concentration of condensable vapours. This further suggests that NPF is most likely to occur soon after ma- rine air masses arrive on the continent and become enriched with condensable vapours. Tunved et al. (2006) reported time scales for the evolution of nucleation mode particle concentrations measured in Pallas comparable to the NPF probabilities found in this study.

\subsection{Inter-annual variability}

The NPF frequency suggested a decreasing tendency between years 2000 and 2003, whereafter an increasing trend was observed (Fig. 11). As presented above, there are several factors which might favour or hinder NPF, one of the clearest being the air mass origin and meteorological variables. Using the NPF-proxy presented in Fig. 5, the effect of changing environmental conditions on the inter-annual variation of NPF was studied. It was discovered that meteorological variability between the years accounted for a very minor fraction of the observed variation in NPF frequency (Fig. 11). The NPF frequency predicted by the proxy showed a minor increase between the years 2004 and 2010, consistent with observations but especially the observed dip in NPF in 2003 remained unpredicted. NPF was also correlated with other known proxies, such as sulphuric acid concentration, condensation sink and biogenic emissions but none of these alone were able to explain the observed inter-annual variability, and in particular, the low NPF frequency in 2003.

Kulmala et al. (2010) presented the number of NPF events observed in Hyytiälä, Southern Finland, between years 1996 and 2008, which can be compared to our results. The interannual variability found in Hyytiälä is very different from that in Pallas; the maximum in the number of NPF events was found in 2003 when a minimum was detected in Pallas.

Interestingly, the observed inter-annual variability of median GR showed some similarities with that of the NPF frequency, both having minimum in 2003 and maximum in 2010 (Fig. 12). In 2003, the median GR was only around $1 \mathrm{~nm} \mathrm{~h}^{-1}$, while it was over $3 \mathrm{~nm} \mathrm{~h}^{-1}$ in 2010 . Variation of GR around its median (absolute difference between 25 and 75 percentiles) was similar in magnitude in all years: around $2-3 \mathrm{~nm} \mathrm{~h}^{-1}$. Connection of NPF frequency with GR might suggest that in the lack of sufficient vapour concentrations events are both rare and weak (i.e. GR is low), and do not thereby inflict significant climatic effects. Unfortunately, the lowest detection limit of $7 \mathrm{~nm}$ in this study hinders a further separation of the actual nucleation process and the further growth, which are not necessarily dominated by the same vapours.

In contrast, a clear pattern in inter-annual variability of particle formation rates was not detected and the $\mathrm{FR}_{7}$ median values were of the same order of magnitude in all years.

\subsection{CCN formation from NPF}

For lack of direct CCN measurements in Pallas, we estimated the contribution of nucleation to $\mathrm{CCN}$ production from 


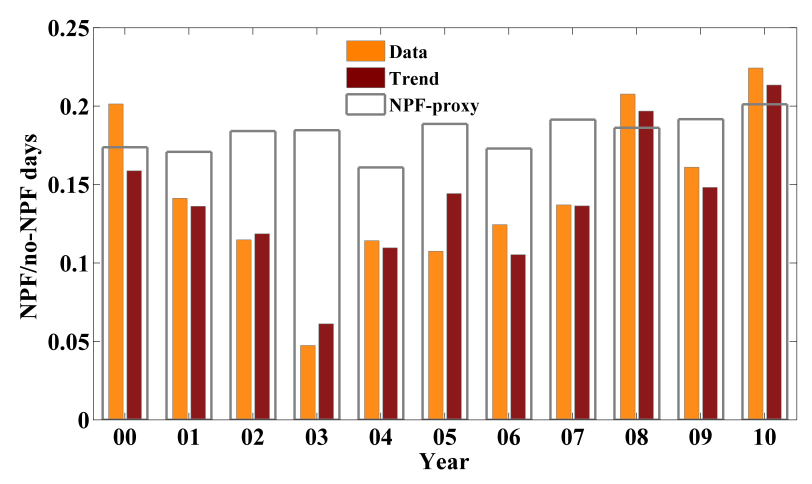

Fig. 11. Inter-annual variation of NPF/no-NPF days. Data bars contain only measured data while the missing values have been replaced by the monthly statistics in trend estimation (presented by trend bars). Inter-annual variation of NPF/no-NPF days estimated based on NPF-proxy take into account the air mass frequencies, global radiation and visibility changes.

continuous particle number size distribution measurements by following the approach introduced by Lihavainen et al. (2003). As a first step, this requires defining the size above which nucleated particles need to grow to become CCN. Komppula et al. (2005) measured the activation diameter in Pallas by comparing the interstitial and whole aerosol size distributions and found that the average threshold diameter for cloud droplet activation, i.e. the minimum dry particle diameter for which the probability of cloud droplet activation exceeds $50 \%$, is $80 \mathrm{~nm}$, with values ranging from 50 to $128 \mathrm{~nm}$. We assumed here that particles $>80 \mathrm{~nm}$ in diameter are $\mathrm{CCN}$ and called their total number concentration as $\mathrm{CCN}_{80}$. As a second step, we estimated whether and how much each nucleation event enhanced the value of $\mathrm{CCN}_{80}$. This was done by first calculating the average value of $\mathrm{CCN}_{80}$ from the beginning of the nucleation event up to the time when the nucleation mode had reached the $80 \mathrm{~nm}$ size, and by subtracting this value from $\mathrm{CCN}_{80}$ reached by the end of the nucleation event. For sensitivity purposes, we repeated the above procedure for particles $>50 \mathrm{~nm}\left(\mathrm{CCN}_{50}\right)$ and $>100 \mathrm{~nm}\left(\mathrm{CCN}_{100}\right)$ in diameter.

We found that in $34 \%$ of the observed class I nucleation events, particles grew above $80 \mathrm{~nm}$ to produce new $\mathrm{CCN}$. This percentage varied strongly with season, being $65 \%$ in summer, $67 \%$ in autumn, $0 \%$ in winter and $19 \%$ in spring. Using the CCN limits of 50 and $100 \mathrm{~nm}$ led to CCN production in 53 and $24 \%$ of the cases, respectively. The potential of nucleation to form new $\mathrm{CCN}$ was highest during the summer-autumn period, which can be ascribed to the largest particle growth rates during this part of the year (see Fig. 7). We should note that our approach was unable to take into account potential changes in particle $\mathrm{CCN}$ activation properties between the different seasons, as has been observed by

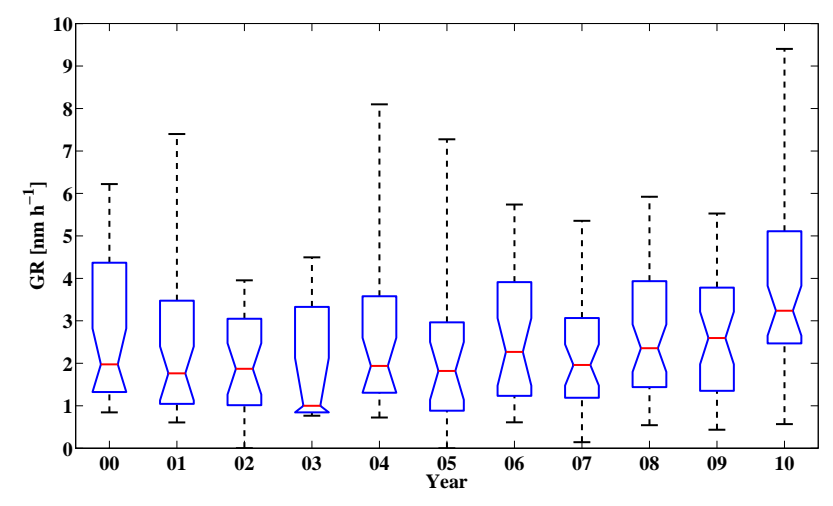

Fig. 12. Growth rate (GR) variability in class I events between the years. The boxes show upper and lower quartiles, and median with red line. The whiskers extend from minimum to maximum GR value.

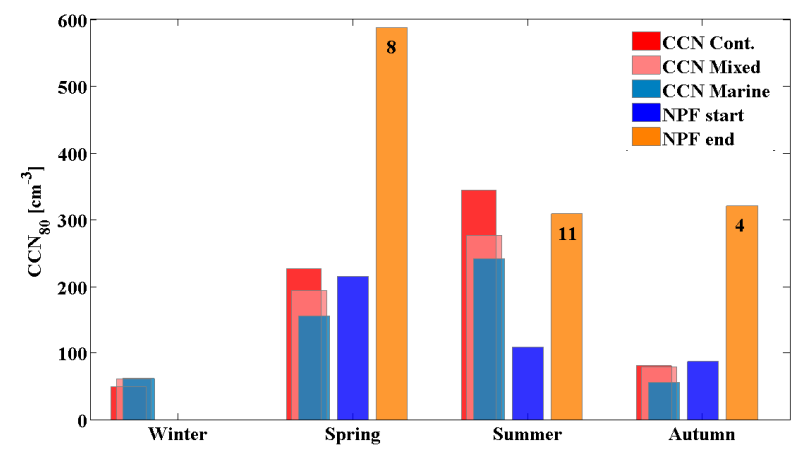

Fig. 13. $\mathrm{CCN}_{80}$ formation in class I events compared with median $\mathrm{CCN}_{80}$ concentrations in different seasons separated between different air masses. Bars "CCN Cont.", "CCN Mixed" and "CCN Marine" present the median concentration of $>80 \mathrm{~nm}$ particles $\left(\mathrm{CCN}_{80}\right)$ in continental, mixed, and marine air masses, respectively, and include all: event, undefined, and no-event days. Note that most events occur in marine air masses. "NPF start" bars show the median of mean concentrations of $\mathrm{CCN}_{80}$ in the beginning of the event, before the growing mode exceeds $80 \mathrm{~nm}$. "NPF end" bars show the median of mean concentrations after the mode has grown to over $80 \mathrm{~nm}$ size, until the end of the event.

Sihto et al. (2010). The average ( \pm standard deviation) number of new $\mathrm{CCN}_{80}$ produced by all the nucleation events was $280 \pm 180 \mathrm{~cm}^{-3}$ (Fig. 13), which corresponds to the relative increase of $\mathrm{CCN}_{80}$ by $210 \pm 110 \%$. Taking into account also the $66 \%$ of class I events where no new CCN were formed, the relative increase becomes $70 \pm 130 \%$. If we repeat the same analysis for $\mathrm{CCN}_{50}$ and $\mathrm{CCN}_{100}$, the corresponding increases in CCN concentrations were equal to $160 \pm 270$ and $50 \pm 130 \%$.

Sihto et al. (2010) investigated the connection between nucleation and CCN formation in Hyytiälä, southern Finland, 
based on about a year of simultaneous $\mathrm{CCN}$ and particle number size distribution measurements. Depending on saturation ratio, they observed the nucleation events to enhance CCN concentrations by $70-110 \%$. The difference in the relative enhancement in $\mathrm{CCN}$ concentrations between the study of Sihto et al. (2010) and ours in understandable when considering the apparent differences in background particle number concentrations and nuclei growth rates between the two sites (e.g., Dal Maso et al., 2007; Lihavainen et al., 2009), as well as the somewhat different approaches used to estimate $\mathrm{CCN}$ concentrations. Both these studies demonstrate, however, that nucleation has the potential to enhance $\mathrm{CCN}$ concentrations considerably over boreal forests during the summer.

\section{Summary and conclusions}

Over 10-years of new particle formation (NPF) events were analysed from the Finnish sub-Arctic Pallas station. The NPF frequency was shown to have a pronounced seasonal cycle with a spring maximum and a winter minimum. The monthly average $7 \mathrm{~nm}$ particle formation rate remained around 0.1 to $0.2 \mathrm{~cm}^{-3} \mathrm{~s}^{-1}$ throughout the year. The particle growth rates were the lowest in spring when the monthly averages were around $2 \mathrm{~nm} \mathrm{~h}^{-1}$ and the highest in summer with averages around $4 \mathrm{~nm} \mathrm{~h}^{-1}$. Based on calculated sulphuric acid proxy concentrations, only a minor part of the growth could be explained by sulphuric acid condensation. Following the previous studies and considering the seasonal cycle of the growth rates this suggests that oxidation of biogenic precursors is crucial for particle growth to $\mathrm{CCN}$ sizes.

New particle formation was frequently observed in marine Arctic and Atlantic air masses, while only sporadic events were observed in continental air flows. Marine air masses seemed to hold many of the meteorological features favourable for particle formation. However, even if compared to the air mass median meteorological parameter values, high radiation and visibility further increased the NPF probability in marine air masses, while high $\mathrm{RH}$, rain and low visibility suppressed NPF. The effect of temperature was not evident. However, the results propose that the temperature might have a role through increased biogenic emissions in warmest summer months for increasing the particle growth rates, but not necessarily the NPF probability.

Inter-annual variation of NPF frequency showed a minimum in 2003 which remained unexplained by the variation of meteorological, air mass origin or particle or vapour sink terms. A similar inter annual trend in particle growth rates could be indicative of a minimum in particle organic precursors in 2003, which were not measured. Additionally, the recent studies suggest that with low total particle formation rates, as those observed in Pallas, the relative importance of ion-induced nucleation mechanism increases (Kirkby et al., 2011; Manninen et al., 2010). The minimum in cosmic ray induced ionisation intensity around years 2002-2003 (Kulmala et al., 2010), coinciding with the minimum in the observed event frequency here, further encourages for more detailed studies on the connections between galactic cosmic rays and new particle formation mechanisms at the Pallas site.

Secondary new particle formation was recognised as a potentially significant source of cloud condensation nuclei: for cases when the growing mode exceeded $80 \mathrm{~nm}$ diameter, $210 \pm 110 \%$ increase in $\mathrm{CCN}_{80}$ concentrations was observed. Including all class I NPF events (even if no growth $>80 \mathrm{~nm}$ could be detected), the increase equals to $70 \pm 130 \%$. In spring and autumn seasons, this corresponded to an $\mathrm{CCN}_{80}$ concentration increase well above its average value while in summer, NPF increase the $\mathrm{CCN}_{80}$ concentrations to a typical level. It appears that NPF was maintaining the $\mathrm{CCN}_{80}$ concentrations in summer while on other seasons, it produced particles adding to the typical $\mathrm{CCN}$ levels.

The major findings of this 10-year NPF analysis confirm the results of previous studies made in Pallas and in other Nordic stations (Dal Maso et al., 2007; Komppula et al., 2005, 2003; Kristensson et al., 2008; Vehkamäki et al., 2004). The formation and growth rates analysed for two years in Pallas by Komppula et al. (2003) and the potential of NPF to increase $\mathrm{CCN}_{80}$ seem to hold for longer time periods. Similarly, the seasonal and annual event frequencies for years prior to 2004 were confirmed in this study, which states that despite the subjectivity of the analysis method, the results are not too sensitive for the user input. However, compared to a study by (Dal Maso et al., 2007) a lower fraction of event days was found here, although the general annual features and NPF parameters were alike.

The principal difficulty which remains to be resolved is the complex coupling between several factors affecting atmospheric NPF. While some relations between NPF parameters, frequency and probability with several atmospheric variables can be distinguished, resolving their mutual dependencies and unpredictable functional forms would require highly developed non-linear multivariate analysis methods. The analysis is further complicated by the difficulties in reliably determining the sources of errors and their magnitudes for different measured and analysed parameters. Additionally, a comparison of close-by station measurements would benefit the analysis in order to quantify the regionality of the new particle formation events as well as for obtaining better statistics. 
Acknowledgements. The financial support from Maj\& Tor Nessling foundation and FCoE (Finnish Center of Excellence of Academy of Finland, project no. 1118615) are greatfully acknowledged.

\section{Edited by: R. Krejci}

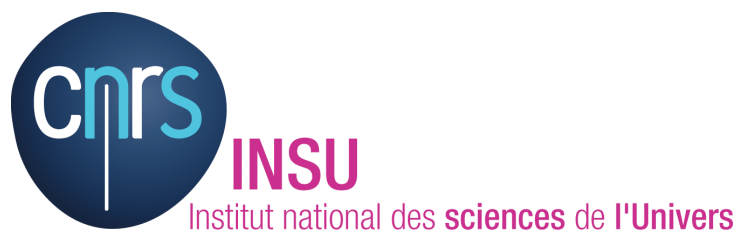

The publication of this article is financed by CNRS-INSU.

\section{References}

Aalto, T., Hatakka, J., Paatero, J., Tuovinen, J.-P., Aurela, M., Laurila, T., Holmén, K., Trivett, N., and Viisanen, Y.: Tropospheric carbon dioxide concentrations at a northern boreal site in Finland: Basic variations and source areas, Tellus, Ser. B, 54, 110 126, 2002.

Benson, D. R., Yu, J. H., Markovich, A., and Lee, S.-H.: Ternary homogeneous nucleation of $\mathrm{H}_{2} \mathrm{SO}_{4}, \mathrm{NH}_{3}$, and $\mathrm{H}_{2} \mathrm{O}$ under conditions relevant to the lower troposphere, Atmos. Chem. Phys., 11, 4755-4766, doi:10.5194/acp-11-4755-2011, 2011.

Berndt, T., Stratmann, F., Sipilä, M., Vanhanen, J., Petäjä, T., Mikkilä, J., Grüner, A., Spindler, G., Mauldin III, L. R., Curtius, J., Kulmala, M., and Heintzenberg, J.: Laboratory study on new particle formation from the reaction $\mathrm{OH}+\mathrm{SO}_{2}$ : influence of experimental conditions, $\mathrm{H} 2 \mathrm{O}$ vapour, $\mathrm{NH}_{3}$ and the amine tert-butylamine on the overall process, Atmos. Chem. Phys., 10, 7101-7116, doi:10.5194/acp-10-7101-2010, 2010.

Brus, D., Neitola, K., Hyvärinen, A.-P., Petäjä, T., Vanhanen, J., Sipilä, M., Paasonen, P., Kulmala, M., and Lihavainen, H.: Homogenous nucleation of sulfuric acid and water at close to atmospherically relevant conditions, Atmos. Chem. Phys., 11, 52775287, doi:10.5194/acp-11-5277-2011, 2011.

Buenrostro Mazon, S., Riipinen, I., Schultz, D. M., Valtanen, M., Dal Maso, M., Sogacheva, L., Junninen, H., Nieminen, T., Kerminen, V.-M., and Kulmala, M.: Classifying previously undefined days from eleven years of aerosol-particle-size distribution data from the SMEAR II station, Hyytiälä, Finland, Atmos. Chem. Phys., 9, 667-676, doi:10.5194/acp-9-667-2009, 2009.

Birmili, W., Berresheim, H., Plass-Dlmer, C., Elste, T., Gilge, S., Wiedensohler, A., and Uhrner, U.: The Hohenpeissenberg aerosol formation experiment (HAFEX): a long-term study including size-resolved aerosol, $\mathrm{H}_{2} \mathrm{SO}_{4}, \mathrm{OH}$, and monoterpenes measurements, Atmos. Chem. Phys., 3, 361-376, doi:10.5194/acp-3-361-2003, 2003.

Dal Maso, M., Kulmala, M., Riipinen, I., Wagner, R., Hussein, T., Aalto, P. P., and Lehtinen, K. E. J.: Formation and growth of fresh atmospheric aerosols: eight years of aerosol size distribution data from SMEAR II, Hyytiälä, Finland, Boreal Environ. Res., 10, 323-336, 2005

Dal Maso, M., Sogacheva, L., Aalto, P. P., Riipinen, I., Komppula, M., Tunved, P., Korhonen, L., Suur- Uski, V., Hirsikko, A.,
Kurtén, T., Kerminen, V.-M., Lihavainen, H., Viisanen, Y., Hansson, H.-C., and Kulmala, M.: Aerosol size distribution measurements at four Nordic field stations: identification, analysis and trajectory analysis of new particle formation bursts, Tellus, 59B, 350-361, 2007.

Gagné, S., Nieminen, T., Kurtén, T., Manninen, H. E., Petäjä, T., Laakso, L., Kerminen, V.-M., and Kulmala, M.: Factors influencing the contribution of ion-induced nucleation in a boreal forest, Finland, Atmos. Chem. Phys., 10, 3743-3757, doi:10.5194/acp10-3743-2010, 2010.

Hamed, A., Joutsensaari, J., Mikkonen, S., Sogacheva, L., Dal Maso, M., Kulmala, M., Cavalli, F., Fuzzi, S., Facchini, M. C., Decesari, S., Mircea, M., Lehtinen, K. E. J., and Laaksonen, A.: Nucleation and growth of new particles in Po Valley, Italy, Atmos. Chem. Phys., 7, 355-376, doi:10.5194/acp-7-355-2007, 2007.

Hamed, A., Korhonen, H., Sihto, S.-L., Joutsensaari, J., Järvinen, H., Petäjä, T., Arnold, F., Nieminen, T., Kulmala, M., Smith, J. N., Lehtinen, K. E. J., and Laaksonen, A.: The role of relative humidity in continental new particle formation, J. Geophys. Res., 116, D03202, doi:10.1029/2010JD014186, 2011.

Hirsikko, A., Nieminen, T., Gagné, S., Lehtipalo, K, Manninen, H. E., Ehn, M., Hõrrak, U., Kerminen, V.-M., Laakso, L., McMurry, P. H., Mirme, A., Mirme, S., Petäjä, T., Tammet, H., Vakkari, V., Vana, M., and Kulmala, M.: Atmospheric ions and nucleation: a review of observations, Atmos. Chem. Phys., 11, 767-798, 2011, http://www.atmos-chem-phys.net/11/767/2011/.

Hussein, T., Junninen, H., Tunved, P., Kristensson, A., Dal Maso, M., Riipinen, I., Aalto, P. P., Hansson, H.-C., Swietlicki, E., and Kulmala, M.: Time span and spatial scale of regional new particle formation events over Finland and Southern Sweden, Atmos. Chem. Phys., 9, 4699-4716, doi:10.5194/acp-9-4699-2009, 2009.

Kazil, J., Harrison, R. G., and Lovejoy, E. R.: Tropospheric new particle formation and the role of ions, Space Sci. Rev., 137, 241255, 2008.

Kazil, J., Stier, P., Zhang, K., Quaas, J., Kinne, S., O’Donnell, D., Rast, S., Esch, M., Ferrachat, S., Lohmann, U., and Feichter, J.: Aerosol nucleation and its role for clouds and Earth's radiative forcing in the aerosol-climate model ECHAM5-HAM, Atmos. Chem. Phys., 10, 10733-10752, doi:10.5194/acp-1010733-2010, 2010.

Kerminen, V.-M., Lihavainen, H., Komppula, M., Viisanen, Y., and Kulmala, M.: Direct observational evidence linking atmospheric aerosol formation and cloud droplet activation, Geophys. Res. Lett., 32, L14803, doi:10.1029/2005GL023130, 2005.

Kerminen, V.-M., Petäjä, T., Manninen, H. E., Paasonen, P., Nieminen, T., Sipilä, M., Junninen, H., Ehn, M., Gagné, S., Laakso, L., Riipinen, I., Vehkamäki, H., Kurten, T., Ortega, I. K., Dal Maso, M., Brus, D., Hyvärinen, A., Lihavainen, H., Leppä, J., Lehtinen, K. E. J., Mirme, A., Mirme, S., Hõrrak, U., Berndt, T., Stratmann, F., Birmili, W., Wiedensohler, A., Metzger, A., Dommen, J., Baltensperger, U., Kiendler-Scharr, A., Mentel, T. F., Wildt, J., Winkler, P. M., Wagner, P. E., Petzold, A., Minikin, A., Plass-Dülmer, C., Pöschl, U., Laaksonen, A., and Kulmala, M.: Atmospheric nucleation: highlights of the EUCAARI project and future directions, Atmos. Chem. Phys., 10, 10829-10848, doi:10.5194/acp-10-10829-2010, 2010. 
Kirkby, J., Curtius, J., Almeida, J., Dunne, E., Duplissy, J., Ehrhart, S., Franchin, A., Gagné, S., Ickes, L., Kürten, A., Kupc, A., Metzger, A., Riccobono, F., Rondo, L., Schobesberger, S., Tsagkogeorgas, G., Wimmer, D., Amorim, A., Bianchi, F., Breitenlechner, M., David, A., Dommen, J., Downard, A., Ehn, M., Flagan, R. C., Haider, S., Hansel, A., Hauser, D., Jud, W., Junninen, H., Kreissl, F., Kvashin, A., Laaksonen, A., Lehtipalo, K., Lima, J., Lovejoy, E. R., Makhmutov, V., Mathot, S., Mikkilä, J., Minginette, P., Mogo, S., Nieminen, T., Onnela, A., Pereira, P., Petäjä, T., Schnitzhofer, R., Seinfeld, J. H., Sipilä, M., Stozhkov, Y., Stratmann, F., Tomé, A., Vanhanen, J., Viisanen, Y., Vrtala, A., Wagner, P. E., Walther, H., Weingartner, E., Wex, H., Winkler, P. M., Carslaw, K. S., Worsnop, D. R., Baltensperger, U., and Kulmala, M.: Role of sulphuric acid, ammonia and galactic cosmic rays in atmospheric aerosol nucleation, Nature, 476, 429-433, doi:10.1038/nature10343, 2011.

Komppula, M., Lihavainen, H., Hatakka, J., Paatero, J., Aalto, P., Kulmala, M., and Viisanen, Y.: Observations of new particle formation and size distributions at two different heights and surroundings in subarctic area in northern Finland, J. Geophys. Res., 108, D9, doi:10.1029/2002JD002939, 2003.

Komppula, M., Lihavainen, H., Kerminen, V.-M., Kulmala, M., and Viisanen, Y.: Measurements of cloud droplet activation of aerosol particles at a clean subarctic background site, J. Geophys. Res., 110, D06204, doi:10.1029/2004JD005200, 2005.

Komppula, M., Sihto, S.-L., Korhonen, H., Lihavainen, H., Kerminen, V.-M., Kulmala, M., and Viisanen, Y.: New particle formation in air mass transported between two measurement sites in Northern Finland, Atmos. Chem. Phys., 6, 2811-2824, doi:10.5194/acp-6-2811-2006, 2006.

Kristensson, A., Dal Maso, M., Swietlicki, E., Hussein, T., Zhou, J., Kerminen, V.-M., and Kulmala, M.: Characterization of new particle formation events at a background site in Southern Sweden: relation to air mass history, Tellus 60B, 330-344, doi:10.1111/j.1600-0889.2008.00345.x, 2008.

Kuang, C., McMurry, P. H., McCormick, A. V., and Eisele, F. L.: Dependence of nucleation rates on sulfuric acid vapor concentration in diverse atmospheric locations, J. Geophys. Res., 113, D10209, doi:10.1029/2007JD009253, 2008.

Kulmala, M., Toivonen, A., Mäkelä, J. M., and Laaksonen, A.: Analysis of the growth of nucleation mode particles observed in Boreal forest, Tellus, 50B, 449-462, 1998.

Kulmala, M., Dal Maso, M., Mäkelä , J. M., Pirjola, L., Väkevä, M., Aalto, P., Miikkulainen, P., Hämeri, K., and O'Dowd, C.: On the formation, growth, and composition of nucleation mode particles, Tellus, 53B, 479490, 2001.

Kulmala, M., Vehkamäki, H., Petäjä, T., Dal Maso, M., Lauri, A., Kerminen, V.-M., Birmili, W., and McMurry, P.: Formation and growth rates of ultrafine atmospheric particles: a review of observations, J. Aerosol Sci., 35, 143-176, 2004.

Kulmala, M., Lehtinen, K. E. J., and Laaksonen, A.: Cluster activation theory as an explanation of the linear dependence between formation rate of $3 \mathrm{~nm}$ particles and sulphuric acid concentration, Atmos. Chem. Phys., 6, 787-793, doi:10.5194/acp-6-787-2006, 2006.

Kulmala, M. and Kerminen, V.-M.: On the formation and growth of atmospheric nanoparticles, Atmos. Res., 90, 132-150, 2008.

Kulmala, M., Riipinen, I., Nieminen, T., Hulkkonen, M., Sogacheva, L., Manninen, H. E., Paasonen, P., Petäjä, T., Dal Maso,
M., Aalto, P. P., Viljanen, A., Usoskin, I., Vainio, R., Mirme, S., Mirme, A., Minikin, A., Petzold, A., Hõrrak, U., Plass-Dülmer, C., Birmili, W., and Kerminen, V.-M.: Atmospheric data over a solar cycle: no connection between galactic cosmic rays and new particle formation, Atmos. Chem. Phys., 10, 1885-1898, doi:10.5194/acp-10-1885-2010, 2010.

Kurtén, T., Loukonen, V., Vehkamäki, H., and Kulmala, M.: Amines are likely to enhance neutral and ion-induced sulfuric acid-water nucleation in the atmosphere more effectively than ammonia, Atmos. Chem. Phys., 8, 4095-4103, doi:10.5194/acp8-4095-2008, 2008.

Laakso, L., Petäjä, T., Lehtinen, K. E. J., Kulmala, M., Paatero, J., Hõrrak, U., Tammet, H., and Joutsensaari, J.: Ion production rate in a boreal forest based on ion, particle and radiation measurements, Atmos. Chem. Phys., 4, 1933-1943, doi:10.5194/acp-41933-2004, 2004.

Laaksonen, A., Hamed, A., Joutsensaari, J., Hiltunen, L., Cavalli, F., Junkermann, W., Asmi, A., Fuzzi, S., and Facchini, M. C.: Cloud condensation nuclei production from nucleation events at a highly polluted region, Geophys. Res. Lett., 32, L06812, doi:10.1029/2004GL022092, 2005.

Lihavainen, H., Kerminen, V.-M., Komppula, M., Hatakka, J., Aaltonen, V., Kulmala, M., and Viisanen, Y.: Production of "potential" cloud concensation nuclei associated with atmospheric newparticle formation in northern Finland, J. Geophys. Res., 108, D24, doi:10.1029/2003JD003887, 2003.

Lihavainen H., Kerminen V.-M., Tunved P., Aaltonen V., Arola A., Hatakka J., Hyvärinen A., and Viisanen Y., Observational signature of the direct radiative effect by natural boreal forest aerosols and its relation to the corresponding first indirect effect, J. Geophys. Res., 114, D20206, doi:10.1029/2009JD012078, 2009.

Makkonen, R., Asmi, A., Korhonen, H., Kokkola, H., Järvenoja, S., Räisänen, P., Lehtinen, K. E. J., Laaksonen, A., Kerminen, V.M., Järvinen, H., Lohmann, U., Bennartz, R., Feichter, J., and Kulmala, M.: Sensitivity of aerosol concentrations and cloud properties to nucleation and secondary organic distribution in ECHAM5-HAM global circulation model, Atmos. Chem. Phys., 9, 1747-1766, doi:10.5194/acp-9-1747-2009, 2009.

Manninen, H. E., Nieminen, T., Asmi, E., Gagné, S., Häkkinen, S., Lehtipalo, K., Aalto, P., Vana, M., Mirme, A., Mirme, S., Hõrrak, U., Plass-Dülmer, C., Stange, G., Kiss, G., Hoffer, A., Töro, N., Moerman, M., Henzing, B., de Leeuw, G., Brinkenberg, M., Kouvarakis, G. N., Bougiatioti, A., Mihalopoulos, N., O’Dowd, C., Ceburnis, D., Arneth, A., Svenningsson, B., Swietlicki, E., Tarozzi, L., Decesari, S., Facchini, M. C., Birmili, W., Sonntag, A., Wiedensohler, A., Boulon, J., Sellegri, K., Laj, P., Gysel, M., Bukowiecki, N., Weingartner, E., Wehrle, G., Laaksonen, A., Hamed, A., Joutsensaari, J., Petäjä, T., Kerminen, V.-M., and Kulmala, M.: EUCAARI ion spectrometer measurements at 12 European sites - analysis of new particle formation events, Atmos. Chem. Phys., 10, 7907-7927, doi:10.5194/acp-10-79072010, 2010.

McMurry, P. H. and Friedlander, S. K.: New particle formation in the presence of aerosol, Atmos. Environ., 13, 1635-1651, 1979.

Merikanto, J., Spracklen, D. V., Mann, G. W., Pickering, S. J., and Carslaw, K. S.: Impact of nucleation on global CCN, Atmos. Chem. Phys., 9, 8601-8616, doi:10.5194/acp-9-8601-2009, 2009.

Merikanto, J., Spracklen, D. V., Pringle, K. J., and Carslaw, K. 
S.: Effects of boundary layer particle formation on cloud droplet number and changes in cloud albedo from 1850 to 2000, Atmos. Chem. Phys., 10, 695-705, doi:10.5194/acp-10-695-2010, 2010.

Metzger, A., Verheggen, B., Dommen, J., Duplissy, J., Prevot, A. S. H., Weingartner, E., Riipinen, I., Kulmala, M., Spracklen, D. V., Carslaw, K. S., and Baltensperger, U.: Evidence for the role of organics in aerosol particle formation under atmospheric conditions, Proc. Nat. Acad. Sci., 107, 6645-6651, doi:10.1073/pnas.0911330107, 2010.

Mäkelä, J., Dal Maso, M., Pirjola, L., Keronen, P., Laakso, L., Kulmala, M., and Laaksonen, A.: Characteristics of the atmospheric particle formation events observed at a boreal forest site in southern Finland, Boreal Environ. Res., 5, 299-313, 2000.

Neitola, K., Asmi, E., Komppula, M., Hyvärinen, A.-P., Raatikainen, T., Panwar, T. S., Sharma, V. P., and Lihavainen, H.: New particle formation infrequently observed in Himalayan foothills - why?, Atmos. Chem. Phys., 11, 8447-8458, doi:10.5194/acp-11-8447-2011, 2011.

O’Dowd, C. D., Jimenez, J. L., Bahreini, R., Flagan, R. C., Seinfeld, J. H., Hämeri, K., Pirjola, L., Kulmala, M., Jennings, S. G., and Hoffmann, T.: Marine aerosol formation from biogenic iodine emissions, Nature, 417, 632-636, 2002.

O'Dowd, C., Monahan, C., and Dall'Osto, M.: On the occurrence of open ocean particle production and growth events, Geophys. Res. Lett., 37, L19805, doi:10.1029/2010GL044679, 2010.

Paasonen, P., Nieminen, T., Asmi, E., Manninen, H. E., Petäjä, T., Plass-Dülmer, C., Flentje, H., Birmili, W., Wiedensohler, A., Hõrrak, U., Metzger, A., Hamed, A., Laaksonen, A., Facchini, M. C., Kerminen, V.-M., and Kulmala, M.: On the roles of sulphuric acid and low-volatility organic vapours in the initial steps of atmospheric new particle formation, Atmos. Chem. Phys., 10, 11223-11242, doi:10.5194/acp-10-11223-2010, 2010.

Petäjä, T., Mauldin, III, R. L., Kosciuch, E., McGrath, J., Nieminen, T., Paasonen, P., Boy, M., Adamov, A., Kotiaho, T., and Kulmala, M.: Sulfuric acid and $\mathrm{OH}$ concentrations in a boreal forest site, Atmos. Chem. Phys., 9, 7435-7448, doi:10.5194/acp9-7435-2009, 2009.

Pierce, J. R. and Adams, P. J.: Uncertainty in global CCN concentrations from uncertain aerosol nucleation and primary emission rates, Atmos. Chem. Phys., 9, 1339-1356, doi:10.5194/acp-91339-2009, 2009.

Riipinen, I., Sihto, S.-L., Kulmala, M., Arnold, F., Dal Maso, M., Birmili, W., Saarnio, K., Teinilä, K., Kerminen, V.-M., Laaksonen, A., and Lehtinen, K. E. J.: Connections between atmospheric sulphuric acid and new particle formation during QUEST IIIIV campaigns in Heidelberg and Hyytiälä, Atmos. Chem. Phys., 7, 1899-1914, doi:10.5194/acp-7-1899-2007, 2007.

Sihto, S.-L., Mikkilä, J., Vanhanen, J., Ehn, M., Liao, L., Lehtipalo, K., Aalto, P. P., Duplissy, J., Petäjä, T., Kerminen, V.-M., Boy, M., and Kulmala, M.: Seasonal variation of CCN concentrations and aerosol activation properties in boreal forest, Atmos. Chem. Phys. Discuss., 10, 28231-28272, doi:10.5194/acpd-10-282312010, 2010.

Sipilä, M., Berndt, T., Petäjä, T., Brus, D., Vanhanen, J., Stratmann, F., Patokoski, J., Mauldin III, R. L., Hyvärinen, A.-P., Lihavainen, H., and Kulmala, M.: The role of sulfuric acid in atmospheric nucleation, Science, 327, 1243-1246, 2010.

Smith, J. N., Barsanti, K. C., Friedli, H. R., Ehn, M., Kulmala, M., Collins, D. R., Scheckman, J., Williams, B. J., and McMurry,
P. H.: Observations of aminium salts in atmospheric nanoparticles and possible climatic implications, Proc. Nat. Acad. Sci., 107, 6634-6639, doi:10.1073/pnas.0912127107, 2010.

Sogacheva, L., Saukkonen, L., Nilsson, E. D., Dal Maso, M., Schultz, D. M., De Leeuw, G., and Kulmala, M.: New aerosol particle formation in different synoptic situations at Hyytiälä, Southern Finland, Tellus, 60B, 485-494, 2008.

Spracklen, D. V., Carslaw, K. S., Kulmala, M., Kerminen, V.-M., Mann, G. W., and Sihto, S.-L.: The contribution of boundary layer nucleation events to total particle concentrations on regional and global scales, Atmos. Chem. Phys., 6, 5631-5648, doi:10.5194/acp-6-5631-2006, 2006.

Spracklen, D. V., Carslaw, K. S., Merikanto, J., Mann, G. W., Reddington, C. L., Pickering, S., Ogren, J. A., Andrews, E., Baltensperger, U., Wiengartner, E., Boy, M., Kulmala, M., Laakso, L., Lihavainen, H., Kivekäs, N., Komppula, M., Mihalopoulos, N., Kouvarakis, G., Jennings, S. G., O’Dowd, C., Birmili, W., Wiedensohler, A., Weller, R., Gras, J., Laj, P., Sellegri, K., Bonn, B., Krejci, R., Laaksonen, A., Hamed, A., Minikin, A., Harrison, R. M., Talbot, R., and Sun, J.: Explaining global surface aerosol number concentrations in terms of primary emissions and particle formation, Atmos. Chem. Phys., 10, 4775-4793, doi:10.5194/acp-10-4775-2010, 2010.

Stohl, A., and Seibert, P.: Accuracy of trajectories as determined from the conservation of meteorological tracers, Q. J. Roy. Met. Soc., 124, 1465-1484, 1998.

Stohl, A., Wotawa, G., Seibert, P., and Kromp-Kolb, H.: Interpolation errors in wind fields as a function of spatial and temporal resolution and their impact on different types of kinematic trajectories, J. Appl. Meteor., 34, 2149-2165, 1995.

Suni, T., Kulmala, M., Hirsikko, A., Bergman, T., Laakso, L., Aalto, P. P., Leuning, R., Cleugh, H., Zegelin, S., Hughes, D., van Gorsel, E., Kitchen, M., Vana, M., Hõrrak, U., Mirme, S., Mirme, A., Sevanto, S., Twining, J., and Tadros, C.: Formation and characteristics of ions and charged aerosol particles in a native Australian Eucalypt forest, Atmos. Chem. Phys., 8, 129-139, doi:10.5194/acp-8-129-2008, 2008.

Tunved, P., Hansson, H.-C., Kerminen, V.-M., Ström, J., Dal Maso, M., Lihavainen, H., Viisanen, Y., Aalto, P. P., Komppula, M., and Kulmala, M.: High natural aerosol loading over boreal forests, Science, 312, 261-263, 2006.

Vehkamäki, H., Dal Maso, M., Hussein, T., Flanagan, R., Hyvärinen, A., Lauros, J., Merikanto, J., Mönkkönen, P., Pihlatie, M., Salminen, K., Sogacheva, L., Thum, T., Ruuskanen, T. M., Keronen, P., Aalto, P. P., Hari, P., Lehtinen, K. E. J., Rannik, $\ddot{U}$, and Kulmala, M.: Atmospheric particle formation events at Värriö measurement station in Finnish Lapland 1998-2002, Atmos. Chem. Phys., 4, 2015-2023, doi:10.5194/acp-4-2015-2004, 2004.

Vuollekoski, H., Kerminen, V.-M., Anttila, T., Sihto, S.-L., Vana, M., Ehn, M., Korhonen, H., McFiggans, G., O’Dowd, C. D., and Kulmala, M.: Iodine dioxide nucleation simulations in coastal and remote marine environments, J. Geophys. Res., 114, D02206, doi:10.1029/2008JD010713, 2009.

Wang, M. and Penner, J. E.: Aerosol indirect forcing in a global model with particle nucleation, Atmos. Chem. Phys., 9, 239-260, doi:10.5194/acp-9-239-2009, 2009.

Weber, R. J., Marti, J. J., McMurry, P. H., Eisele, F. L., Tanner, D. J., and Jefferson, A.: Measured atmospheric new particle for- 
mation rates : Implications for nucleation mechanisms, Chem. Eng. Commun., 151, 53-64, 1996.

Wiedensohler, A., Cheng, Y. F., Nowak, A., Wehner, B., Achtert, P., Berghof, M., Birmili, W., Wu, Z. J., Hu, M., Zhu, T., Takegawa, N., Kita, K., Kondo, Y., Lou, S. R., Hofzumahaus, A., Holland, F., Wahner, A., Gunthe, S. S., Rose, D., Su, H., and Pöschl, U.: Rapid aerosol particle growth and increase of cloud condensation nucleus activity by secondary aerosol formation and condensation: A case study for regional air pollution in northeastern China, J. Geophys. Res., 114, D00G08, doi:10.1029/2008JD0101884, 2009.
Yu, F., Luo, G., Bates, T. S., Andersson, B., Clarke, A., Kapustin, V., Yantosca, R. M., Wang, Y., and Wu, S.: Spatial distributions of particle number concentrations in the global troposphere: Simulations, observations, and implications for nucleation mechanism, J. Geophys. Res., 115, D17205, doi:10.1029/2009JD013473, 2010 b.

$\mathrm{Yu}, \mathrm{F}$. Ion-mediated nucleation in the atmosphere: Key controlling parameters, implications, and look-up table, J. Geophys. Res., 115, D03206, doi:10.1029/2009JD012630, 2010a. 